\title{
The international entrepreneurial firms' social networks
}

\author{
Manuel Portugal Ferreira ${ }^{1}$ \\ João Carvalho Santos ${ }^{2}$ \\ Fernando A. Ribeiro Serra ${ }^{3}$
}

\begin{abstract}
This paper investigates theoretically the importance and impact of the international entrepreneurial firms' (IEFs) social networks on selected firms' strategies. We focus specifically on some core attributes of IEFs and the impact of social networks on such strategies as the choice of the foreign markets to operate and the foreign entry modes. The social networks are a major driver of the internationalization from inception and help in overcoming a variety of physical and social resource limitations as well as transactional hazards. We conclude that it is likely that both some fundamental characteristics of the IEFs and those of the foreign markets entered account for these firms reliance on their social networks.
\end{abstract}

Keywords: entrepreneurship, international entrepreneurial firms, social networks, internationalization, strategy

\section{Introduction}

International entrepreneurial firms (IEFs) have been an emerging phenomenon since the beginning of the 1990s. The opening of national boundaries and markets to foreign products, finance and labor has led many firms across a variety of geographic and product markets and industries to search for international expansion. Some of these firms seek foreign markets since inception. The upsurge of born-international firms, or bornglobals as the phenomenon is often referred to has contributed to the increasing attention from the management scholars. This attention has further increased after the 1996 Special Issue on IEFs in the journal Entrepreneurship Theory and Practice. In fact, studying IEFs is important (McDougall, 1989; Oviatt \& McDougall, 1994) even to better understand why and how some firms expand and compete internationally with large established firms (see also Mathews \& Zander, 2007). For instance, the Australia's high-value-added manufacturing exporters have witnessed the rise of numerous small and medium-sized companies that successfully compete against large established multinationals in the global business arena (Rennie, 1993).

As scholars have sought to tap into the phenomenon by examining the internationalization of IEFs, inconsistent findings have been reported in prior research. The foreign direct investment (FDI) theories and the evolutionary models of internationalization that were constructed on the basis of the internationalization of large multinational corporations (e.g., Dunning, 1981), have not provided coherent explanations regarding the internationalization activities and progress of IEFs (Coviello \& McAuley, 1999). For instance, while some studies indicate that IEFs follow an incremental internationalization (Dalli, 1994; Chetty \& Hamilton, 1996) much like the large multinational corporations, other studies suggest that IEF are capable of leapfrogging stages in their internationalization (Bell, 1995; Gankema, Snuit \& Van Dijken, 1997). Moreover, other studies indicate

\footnotetext{
${ }^{1}$ Doutor em Gestão de Empresas. Professor de Estratégia no Instituto Politécnico de Leiria - Escola Superior de Tecnologia e Gestãołt globADVANTAGE - Center of Research in International Business \& Strategy. Endereço: Morro do Lena - Alto Vieiro Apartado 4163 - 2411-901 Leiria, PORTUGAL -E-mail: portugal@estg.ipleiria.pt

${ }^{2}$ Doutorando em Gestão. Professor de Estratégia no Instituto Politécnico de Leiria - Escola Superior de Tecnologia e Gestãoct globADVANTAGE - Center of Research in International Business \& Strategy. Endereço:Morro do Lena - Alto Vieiro Apartado 4163 - 2411-901 Leiria, PORTUGAL. E-mail: joao.santosl@estg.ipleiria.pt

${ }^{3}$ Doutor em Engenharia pela Pontifícia Universidade Católica do Rio de Janeiro. Professor do Programa de Pós-graduação em Administração da Universidade do Sul de Santa Catarina - UNISUL. Diretor da Unisul Business School \& globADVANTAGE - Center of Research in International Business \& Strategy. Endereço:Rua Trajano, 219 - Centro - Florianópolis - Brasil - CEP: 88010-010. E-mail: fernando.serra@unisul.br
}

Artigo submetido em dezembro de 2007 e aceito em dezembro de 2008 
that the internationalization process of the born-globals is remarkably different from that of large corporations (Carrier, 1994; Oviatt \& McDougall, 1994).

The extant research on social networks has contributed to the understanding of how entrepreneurs expand their businesses. For instance, some studies using a social networks perspective documented that IEFs are dependent, or at least highly influenced, by the informal social ties of the entrepreneurs themselves (e.g., Bell, 1995; Coviello \& Munro, 1995; Fontes \& Coombs, 1997). The effects of the social ties influence the firms' performance (Stuart \& Poldony, 1996; Lu \& Beamish, 2001) and play a critical role in the internationalization of IEFs (Jarillo, 1988). These observations lead Coviello and McAuley (1999) to suggest that the networking activities are a promising avenue of research in the context of international business (IB). It is further likely that a social networks perspective supplements traditional IB theories in explaining IEFs' internationalization processes in such a wide array of decisions as the host market selection, entry modes adopted, post-entry adaptation, and so forth.

The extant research on IEFs using a social networks perspective has noted that these firms depend on the social relationships but has not yet explained how the IEFs' social networks evolve or why they are so important. It is likely that the IEFs dependence on the social relationships is due to a limited pool of resources to exploit abroad and the lack of capabilities and international experience (e.g., Jarillo, 1989; Beamish, 1999; Lu \& Beamish, 2001) that allow them to explore for new knowledge or novel foreign business opportunities (Knight \& Cavusgil, 2004; Mathews \& Zander, 2007). That is, IEFs seem to suffer cumulatively from the liabilities of smallness (cfr. Hannan \& Freeman, 1989; Baum, 1996), newness (Stinchcombe, 1965; Carroll, 1983), and foreignness (Hymer, 1976). The existing research has failed to tap into the unique factors inherent to IEFs that may explain both the importance of the social networks and the mode of operation of the IEFs in foreign markets.

This paper draws on the entrepreneurship literature (e.g., Miller, 1983; Lumpkin \& Dess, 1996) and the international business research (e.g., Johanson \& Vahlne, 1977; Bell, 1995; Gankema et al., 1997), to explore the factors that lead IEFs to rely on social relationships. In pursuing this goal, we discuss theoretically some characteristics of the IEFs themselves, the selection of foreign markets and the foreign entry modes. Our stated objective is to understand why and how are social networks important for the internationalization of IEFs. In particular analyzing a set of factors specific to the IEFs and their choices, such as market and entry modes selected. As such, this paper also contributes to better understand how firms may use their social networks to foster internationalization. This is particularly valuable for small and medium-sized firms that are comparatively inexperienced in international operations.

The remainder of this paper is organized as follows. First, we briefly review the extant social network literature on international entrepreneurial ventures, focusing on selected characteristics of the firms themselves, the markets selected and the mode of operating in those markets. Inherent to the discussion is the reliance of IEFs on their social networks. We conclude with a broad discussion and present avenues for future inquiry.

\section{Theory review and development}

What is an international entrepreneurial firm (IEF)? In this paper we refer to an IEF as a business organization that takes from inception or very shortly thereafter an innovative, proactive, and risk-taking and risk-sharing behavior to create value by growing and managing its business in multiple countries (Oviatt \& McDougall, 1994). This is a behavior that, as we will discuss, challenges the traditional evolutionary models of internationalization both in respect to the markets selected and the entry modes that are chosen. To further distinguish the IEFs from the established large multinational firms, we focus specifically on those IEFs that have been recently created (that is, that are fairly new), that are small or medium-sized and that are at least reasonably inexperienced in the foreign markets. Hence, pivotal to this conceptualization of what an IEF is, is the crossing of national legal boundaries by relatively new and small firms. 
Organizations are intertwined with their environment, from which they depend to obtain resources (Pfeffer \& Salancik, 1978; Scott, 1998) that are critical for the firms' survival and growth. The organizations' networks provide access to physical resources (Mizruchi \& Galaskiewicz, 1994) and contribute to augment legitimacy (Stuart \& Podolny, 1999). Moreover, firms operating internationally face a wider variety of challenges and agents, needing to learn about the business environment and to adjust to the host foreign markets where they operate (see, for example, Hymer, 1976). To overcome possible liabilities, the IEFs may seek to participate in a network of connected firms to buffer from market uncertainties, resist failure and facilitate growth. Indeed, several studies have shown the importance of international networks for the firms' international expansion (e.g., Majkgard \& Sharma, 1998).

\section{Why are Social Networks Important for International Entrepreneurial Firms?}

The social networks are important for IEFs for a number of reasons. IEFs tend to obtain valuable host country information through their social ties to either local partner firms or other firms operating in those markets (e.g., third-country partners that have specific knowledge on the host country), more often so than established multinational corporations (MNCs). These are relationships with suppliers, customers, financial organizations, industry/commerce associations, and so forth (Oviatt \& McDougall, 1995). The host country knowledge captured from the partners may refer to environmental dimensions on such issues as political, economic, social, cultural, or technological issues. It is not only the international networks that are important but also local, regional and home country networks matter for the international expansion of IEFs. By contrast, the established MNCs are able to rely on their expertise accumulated internally through their own experience in the host country or the region.

A wealth of studies has documented the influence of social networks for IEFs for overcoming resource constraints. By connecting with other organizations, the IEFs gain access to the physical (Bonaccorsi, 1992; Welch, 1992) and informational resources (Larson \& Starr, 1993; Coviello \& Munro, 1995) needed. For instance, Coviello and Munro (1995) showed that foreign market selection and entry initiatives are originated in opportunities created through the network contacts, suggesting the networks' ability to convey information. Hansen (1999) noted that the IEFs may benefit from the transfer of explicit and tacit knowledge within a network. It is possible that within a network it is easier to identify new relevant knowledge and its transfer is subjected to lower transaction costs (Gulati \& Singh, 1998). Moreover, the participation in a network may improve the IEFs' innovation capabilities. For instance, Stuart and Podolny (1996) observed that small firms connected to large firms perform better in innovations than otherwise. Nonetheless, some IEFs are created without the entrepreneur having established ties to foreign agents or being embedded in any international network. However, it seems reasonable that the international social networks do matter and are frequent drivers of an entrepreneurial push towards creating an initial foreign operation.

The IEFs are more likely to seek to develop host-country-based ties - that is business relationships with local partners. These ties are important vehicles for information, market selection and also ease foreign market entry, while hedging against political hazards. Coviello and Munro $(1995,1997)$ suggested that born-globals frequently emerge due to the rich relationships they have with host markets' agents. For instance, studying the internationalization of Japanese entrepreneurial firms, Lu and Beamish (2001) found that these firms had multiple relationships with local partners and that these connections were positively related to performance. In contrast, MNCs often expand by acquiring existing firms or by establishing their own greenfield foreign subsidiaries. That is, MNCs tend to rely more on self-acquired knowledge and experience, although, in some cases, MNCs may use contractual models to govern a partnership (e.g., alliances or joint ventures with a local or a third-country firm).

The advantages accruing from participating in a network may be sustainable in the long run due to the trust bonds among partners (Bromiley \& Cummings, 1995) and invite the IEFs to build their networks of relationships in both home and host countries. Hence, the network acts as a buffering mechanism against environmental uncertainties by providing access to the physical, financial and social resources needed. In 
proposition form: the international success of an IEF is at least partly determined by its participation in an international network.

In sum, prior literature on IEFs' networks differentiate the social networks held by large MNCs from those of IEFs, their internationalization processes (e.g., Beamish, 1990, 1999; Oviatt \& McDougall, 1994; Lu \& Beamish, 2001), and the strategic role that the social networks play for each type of firm. Specifically, the extant research has shown that IEFs tend to rely more on social networks for accessing various resources, information, and opportunities than established multinationals. That is not to say that networks do not matter for established MNCs. Comparing IEFs with MNCs, we acknowledge that a number of studies indicate that large firms also rely on social networks (see, for example, Jones, Hesterly \& Borgatti, 1997; Mizruchi \& Galaskiewicz, 1994). Notwithstanding, from a strategy standpoint, networking with other organizations is not the only option for large MNCs. The MNCs hold the resources, large manufacturing capacity, their own intelligence systems, and may set up their fully-owned subsidiaries in the host countries. In stark contrast, networking is the only, or at least it is often the best, strategy available for IEFs to explore opportunities in the foreign markets given their resource pool, capabilities, informational constraints and the complexity imposed on operating in international markets (Guisinger, 2001).

\section{The Characteristics of International Entrepreneurial Firms}

The phenomenon we refer as IEF has been coined with different expressions, such as international new ventures (McDougall, Shane \& Oviatt, 1994, 1999; Bloodgood, Sapienza \& Almeida, 1996; Zahra \& George, 2002; Fernhaber, McDougall \& Oviatt, 2007), born globals (Knight \& Cavusgil, 1996, 2004; Madsen \& Servais, 1997; Moen, 2002), global startups (Jolly, Alahuhda \& Jeannet, 1992; Oviatt \& McDougall, 1994, 1995), instant exporters (McAuley, 1999; Preece, Miles \& Baetz, 1999), and micro multinationals (Dimitratos, Johnson, Slow \& Young, 2003). Regardless of the terminology employed, the concept is the outcome of a trend towards the globalization of markets and production that is fuelled by the developments in information systems and technology, transportation, marketing and diminishing tariff and non-tariff barriers. These developments contribute to the birth of entrepreneurial firms with an international orientation from inception, that hold the flexibility to identify and take advantage of the emerging foreign opportunities (Andersson, 2000; Mathews \& Zander, 2007).

The IEFs hold unique characteristics that heighten their need to integrate and rely on social networks. These attributes include their international orientation from inception, the limited pool of physical and social resources from where to draw due to their small size and lack of a track record of achievements, and the entrepreneurial orientation. It may be true that to some extent these traits are also observable in purely domestic entrepreneurial firms, but because IEFs operate in foreign markets they are more salient. We will briefly review three of the main characteristics.

International orientation from inception. The IEFs differ from domestic firms for their international orientation since very early on. For instance, Oviatt and McDougall (1994) and Jantunen, Puumalainen, Saarenketo and Kyläheiko (2005) noted that IEFs often have an international vision from inception, promoting the firms' fast internationalization. At least to some extent, IEFs differ from the traditional large MNCs given that these often rely on accumulated knowledge about the foreign markets to proceed in their internationalization path (Johanson \& Vahlne, 1977; Mathews \& Zander, 2007). The faster internationalization pace of the IEFs is facilitated by their social ties to home and especially host partners - as we noted, these relationships pass on emerging opportunities in the foreign markets. The ties to local networks decrease dramatically the IEFs' perceived risks of operating internationally. The IEFs conceive from inception their marketplace as the world, which is at odds with the traditional approach whereby firms are established and grow within their national boundaries and only later they start looking at proximate countries to expand.

The international orientation may be fuelled by the entrepreneur. Often the entrepreneur has some international experience (Oviatt \& McDougall, 1995; Madsen \& Servais, 1997). A common denominator in IEFs is the importance of the entrepreneur himself (McDougall et al., 1994; Knight \& Cavusgil, 1996; Madsen \& Servais, 
1997) and for the born-international entrepreneurs, the rapid internationalization is the entrepreneurial action that characterizes them. The global vision right from inception is the most important characteristic associated to IEFs (Oviatt \& McDougall, 1995) and that vision may be acquired from prior business experiences of the entrepreneur, or perhaps from a holidays experience or even a spurious contact. In these instances, the IEFs is likely to start operating in those foreign markets about which the entrepreneur has some knowledge and relationships, perhaps in virtue of prior work-related (or holidays) experiences, regardless of whether the markets are more proximate or distant in terms of the psychic distance to the home market. A general proposition reads as follows: form: the early and accelerated internationalization of IEFs is positively related to the social network in which the IEFs' are embedded.

Entrepreneurial Behaviour. International new ventures are characterized by their strong entrepreneurial orientation (Oviatt \& McDougall, 1994; Li \& Ferreira, 2006). The essence of entrepreneurship is entry into a new product/geographic market (Burgelman, 1983), or new (re)combinations of resources (Schumpeter, 1950). To operate in evolving industries collaborative efforts may be required. Usually, the market power of the new firms stems from the intangible assets derived from the possession of advanced technology, marketing skills, or efficient organizational structures (Barney, 1991). The technological capabilities are the IEFs' foundation of sustainable competitive advantages because they are valuable and difficult to imitate (Barney, 1991). However, technologies and corresponding valuable capabilities evolve fast and IEFs have to search for possible collaborations across the globe to keep abreast with the advancements at relatively low cost. This posture is driven by the entrepreneurial orientation that encompasses innovativeness, risk taking and proactiveness. Innovativeness reflects the tendency towards new ideas, novelty, experimentation, and creative processes, while departing from established practices (Lumpkin \& Dess, 1996); proactiveness is the propensity to anticipate and act on future market needs (Lumpkin \& Dess, 1996); risk-taking is the willingness to commit large amounts of resources to projects characterized by highly uncertain outcomes (Miller \& Friesen, 1982).

The entrepreneurial orientation may be related to innovativeness, whether the innovations are related to products, markets or both products and markets. Often the products sold abroad by IEFs are based on some technological development or a new way of doing business. The product-market innovations and technological innovations are an important component of the IEFs' competitive capability and success (Hulsink, Elfring \& Stam, 2008), and it is a fundamental way for the IEFs to pursue new opportunities (Lumpkin \& Dess, 1996). For instance, the IEFs' ability to seize and act on opportunities (i.e., proactiveness) has a positive performance implication in capturing, for instance, first mover advantages (Barringer \& Bluedorn, 1999). There is extensive research documenting how firms benefit from cooperative ties to promote innovativeness, and for small entrepreneurial firms these ties are even more crucial to pool together the required resources for R\&D or even to obtain access to knowledge developed externally.

The IEFs have a tendency to engage in and support new ideas, novelty, experimentation, and creative processes that may result in new products, services, processes or technologies. According to Schumpeter (1950) an innovation may be simply a recombination of existing technologies or skills. According to Kimberly (1981), innovation often leads small firms to depart from their original business or practice and venture beyond the current state of art. It has been long argued that social networks are an important vehicle for organizational innovation (Ibarra, 1993; Knight \& Cavusgil, 2004; Lamieri e Ietri, 2006). The IEFs build networks that expand their information channels and market exploration abilities, to discover new demands or special customer groups. In proposition form: the IEFs are likely to resort to their social networks to capture novel knowledge and innovations that they may explore both domestically and in foreign markets.

The Small Scale Operations of IEFs. The firms in contemporary business landscape are operating in an environment that is characterized by increased risk and uncertainty, decreased ability to forecast, and shifting industry boundaries (Hitt \& Reed, 2000). In this scenario, the IEFs, compared to large MNCs, face the challenge of maintaining strategic flexibility to compete given resource constraints (Jarillo, 1989; Beamish, 1999). IEFs are not able to compete in the exploitation of scale economies, rather they compete by developing the capability of identifying quickly novel niche markets around the world and establishing cooperative ties to explore and exploit them. In fact, a comparison between IEFs and other internationalized firms (even if these 
are limited to exporting operations) is likely to show that the IEFs are specialized and niche market players (Madsen \& Servais, 1997).

The relatively small size of IEFs implies that these firms have a limited pool of managerial, financial, informational, and human resources (Jarillo, 1989; Beamish, 1999; Coviello \& McAuley, 1999; Lu \& Beamish, 2001). Therefore, the dependence on social networks for resources seems the intrinsic response of IEFs to overcome resource constraints through resource sharing and enhance the likelihood of success. The extant research supports this argument. For example, Fontes and Coombs (1997) observed that firms established relationships with other organizations to complement their activities or compensate for deficiencies (e.g., use local intermediaries or develop relationship with larger firms). In the same vein, Holmlund and Kock (1998) found that business networks allowed IEFs to access information and other resources.

The IEFs' flexibility is facilitated by networks partially because of the easier and more abundant access to information (Granovetter, 1985; Dyer \& Singh, 1998) that leads to better chances to detect new opportunities in international markets. Simultaneously, as Zahra, Ireland and Hitt (2000) noted, the IEFs can benefit from learning novel technologies from their partners and speed their internationalization. Operational flexibility is essential to take advantage and explore-exploit the emerging opportunities. Through the collaborative ties among independent firms, the IEFs reduce the investment requirements in fixed assets, and maintain enough flexibility to switch to new businesses. A general proposition may be formulated as follows: the small scale of operations of IEFs (and their pursuit for maintaining flexibility) requires a social network of relationships to identify and explore market-related opportunities.

The above discussed characteristics may, at least partially, contribute to disentangle the conflict between the traditional internationalization theories that highlight an incremental internationalization process (cfr. Johanson \& Vahlne, 1977), and those based on the observation that the internationalization process is faster for small entrepreneurial firms (Knight \& Cavusgil, 1996; McDougall et al., 1994; Shrader, Oviatt, \& McDougall, 2000). These two disparate internationalization patterns highlight the role of social networks with international partners, as we discuss below.

\section{The Markets Where IEFs Operate}

In this section of the paper we suggest that the foreign markets sought by the IEFs influence the extent to which the social networks are important for IEFs. These firms seek, from inception, to gain a competitive advantage from using their resources or capturing sales in multiple countries (Oviatt \& McDougall, 1994). For instance, it seems reasonable to suggest that the geographic location of the IEFs is at least influenced by the entrepreneurs' prior foreign experiences, or by the economic capacity and demand conditions of the recipient market. Possibly, the international expansion of the IEFs is related to the ability to access $\mathrm{R} \& \mathrm{D}$, distribution channels or some innovative skill, probably in partnership with other firms across product and geographic markets. Moreover, it is likely that IEFs need to rely more often than large firms on strategic outsourcing ties to other firms through networks ties that may entail the formation of a joint venture or a strategic alliance (Madsen \& Servais, 1997).

Looking at the country of origin of the IEFs it is further reasonable to draw from the well established international business literature on the internationalization processes of firms. Firms in small domestic markets tend to have a higher propensity to be born-globals since the domestic market may not suffice to absorb their production. That is, the new entrepreneurial endeavours may need to be international from inception to have a viable market demand potential. Note that this rationale was explored by the Uppsala School (see, for example, Johanson \& Vahlne, 1977, 1990). An implicit proposition is thus that: the IEFs are more likely to emerge in smaller countries, in comparison to large countries. The internationalization of the IEFs is further likely to be promoted through network ties to other domestic and foreign firms.

The IEFs are generally oriented towards relatively small market segments - the international niche markets where they are able to avoid direct competition with the MNCs (Davis \& Austerberry, 1999) and generate a profit. Although new IEFs are at a disadvantage when competing with large MNCs - note that the MNCs tend 
to concentrate in activities that favor the exploitation of scale and scope economies - the MNCs still tend to raise entry barriers to prevent new entrants (Caves \& Porter, 1977). By focusing in market niches (Baum \& Singh. 1994), the IEFs avoid direct competition. The market niches the IEFs serve are reasonably delimited and, unlike information about mass markets, information about niche markets, and particularly about foreign niches, is often hideous, tacit, and hard to obtain (Schwart, McCorkle \& Anderson, 2000). Acquiring informationabout niche markets requires information channels closer to customers, and is best obtained through collaboration to host country partners (Lu \& Beamish, 2001). Moreover, a market niche usually consists of a narrow group of customers that is difficult to detect and track (Schwart et al., 2000). Therefore, social networks with local players composed of customers, suppliers, family and friends (Larson, 1992) function as a bridge to foreign markets (Coviello \& Munro, 1997). In proposition form: the IEFs rely on their social networks to identify and access foreign market niches.

The international business environment is highly diverse. The markets sought by IEFs have differences across countries, such as customer tastes and preferences, resource endowments, technologies, demand pressures, political environments, legal systems, cultures, income profiles, etc. A firm knowledgeable of these differences can take advantage of opportunities for entrepreneurial behaviors (Dalgic, Li \& Li, 2004). McDougall and Oviatt (1991) suggested that IEF are formed because internationally experienced and alert entrepreneurs are able to link resources from multiple countries to meet the demand of markets that are essentially international. Therefore, the highly fragmented markets that emerge from inter-country differences create unmet demand and international arbitrage opportunities for IEFs.

The IEFs are influenced by the environmental heterogeneity in that, each country has its own culturally determined entrepreneurial propensity (i.e., propensity for innovation, risk-taking behaviours, etc.). Each environment will pose different challenges and opportunities, and is a source of ideas for new product development. While these opportunities may in some instances derive from changes in the social, political, technological, and economic environment, their identification and finding out manners to exploit them require a pool of network ties. That is, the diversity of markets and the differing host markets' characteristics require IEFs do develop distinctive capabilities in acquiring information, or in alternative distinctive ties that provide access to the information. The complexity of operating in international environments (Guisinger, 2001) increases the difficulties for the small IEF, partly due to their limited resource endowment, in building an information system. Hence, the identification of markets' idiosyncrasies, and emerging demand for certain products and services across countries, benefits from social interfaces with local information sources. Based on the above observations, a general proposition is formulated as: the IEFs are likely to use their social networks of relationships to adjust to the specific characteristics of the foreign markets entered.

\section{Modes of Foreign Operation by IEFs}

How small and new firms grow into MNCs has deserved some research attention (Cavusgil, 1980; Johanson \& Vahlne, 1977, 1990; Omar, Nwankwo \& Richards, 2008). The Uppsala model of the firms' internationalization developed by Johanson and Vahlne (1977) focuses on internationalization as a gradual, incremental and evolutionary process of accumulating experience and knowledge over time. This model focuses specially on the entry modes firms select for entering new markets, and posits that firms enter gradually more psychically distant countries (e.g., differences in languages, culture, political and legal systems, etc.). However, this model is not likely to be deterministic and firms may indeed leapfrog stages, as the internationalization paths of IEFs demonstrate (Knight \& Cavusgil, 1996; Madsen \& Servais, 1997). That is IEFs are able to develop a strategy that allows them to internationalize faster than MNCs and shortly after inception.

Some of the best growth opportunities are found in the foreign markets, and that is true also for entrepreneurial firms (Clercq, Sapienza \& Crijus, 2005; Mathews \& Zander, 2007. However, the IEFs face resource constraints (Stinchcombe, 1965; Jarillo, 1989) and do not reasonably hold a broad set of alternative entry modes into the foreign markets as do the larger MNCs. For instance, the IEFs do not have the capacity to acquire established firms in the host markets neither to invest in greenfield start-ups in those markets. The traditional bias towards foreign direct investment operations seems to be far beyond the possibilities of at least most IEFs. In addition, it 
is difficult for entrepreneurs that are unfamiliar with a new country to identify the buyers, suppliers and agents, hence rendering solutions such as the resort to pure market mechanisms (e.g., outsourcing or buy-off-the-shelf exchanges) unattractive.

Foreign market entry modes through pure market transactions is not likely, but entry with governance forms supported in pure hierarchy is also unlikely in IEFs. Given the stereotypical small size of most IEFs compared to established MNCs, they need to access a resource base not yet held. The IEFs must leverage their resources to increase the odds of success when entering the international arena (Jantunen, Puumalainen, Saarenketo \& Kyläheiko, 2005). This is the context that lends itself to search for an hybrid entry strategy (McDougall et al., 1994). The hybrid forms rely on a relationship with another partner(s) (Powell, 1990). In particular, utilizing a partner with some knowledge of the target market by deploying some form of hybrid entry strategies (e.g., licensing, joint ventures, strategic alliances, etc.), is likely to help leveraging the existing IEFs' resources (Oviatt \& McDougall, 1994). However, entering an alliance lends itself to transaction costs hazards particularly those related to the threat of opportunism, adverse selection and moral hazard (Williamson, 1985). The foreign entry mode selected should minimize the transaction costs.

The IEFs' partnerships with other firms may aim at a variety of resources - capital, factories, experiences and expertise, knowledge and even human resources of the partners. For example, Coviello and Munro (1995) found that successful small New Zealand-based software firms are actively involved in international networks, and outsource to network partners several of the manufacturing or market development activities. As such, IEFs seek to ally themselves with other parties that are familiar with the risks of operating in the target market that hold the resources and assets needed but also that offer a solution that minimizes transaction costs. Hence, in this context, it seems reasonable to suggest that by engaging with previously known partners (i.e., prior partners) or firms integrated in the same network promotes these benefits. In proposition form: the IEFs are likely to select partnership-based foreign entry modes, such as strategic alliances with prior partners or other firm in the network.

\section{Discussion and concluding remarks}

In this paper we explore a set of factors that lead IEFs to rely on their social relationships for internationalization, which we accomplish through a theoretical discussion on the IEFs' characteristics, the foreign markets they select and the foreign entry modes chosen. By drawing on the literature on social networks and on international entrepreneurial ventures, we were able to reveal some theory-driven propositions on how social network should influence the likelihood of foreign market opportunity selection and foreign entry modes.

It is now well recognized that expanding internationally poses many threats and exposes firms to a variety of hazards and difficulties (e.g., acquiring needed resources, understanding target market differences, etc.). Although research into international entrepreneurship has been sparse (e.g., Zahra \& George, 2002; Freeman, Edwards \& Schroder, 2006), it is clear that international opportunities for smaller entrepreneurial firms are important. However, entrepreneurial firms face unique problems related to their resource-constrained position (e.g., Karlsen et al., 2003), compared to large established MNCs. Moreover, to take advantage of the emerging opportunities in international markets the IEFs need to maintain strategic flexibility and the capability to act swiftly, which is rather contrary to the traditional strategic planning models of large MNCs. This is the scenario we have when studying international entrepreneurial firms. This paper contributes to our understanding of how can small firms successfully expand internationally. Moreover, it helps our understanding of the capabilities required from IEFs to enter foreign markets.

The social networks are an important vehicle for the IEFs' identification of market-related opportunities, but also to access knowledge, innovations, and physical resources. Moreover, social ties to local agents facilitate local embeddeness. Indeed, it is likely that participating in a social network accelerates the IEFs' internationalization (Mathews \& Zander, 2007). 
The IEFs are born with an entrepreneurial mindset that is internationally oriented (e.g., Oviatt \& McDougall, 1995; De Clercq, Sapienza \& Crijus, 2005). The small size and resource limitations require that the IEFs to avoid direct competition with the large MNCs which they do by focusing on reasonably tight international market niches, as indicated previously. This is an effort that is supported, at least partly, on the identification of new opportunities and differences across national markets. The resource and capability constraints derived from small size and the requirements for early internationalization necessitate the IEFs to deploy their social networks to gain access to the partners' resources. For instance, to spot and explore niche markets and country differences the IEFS need to utilize their social networks as information channels. Moreover, the IEFs must maintain flexibility and a structurally flexible governance form with the partners for each foreign operation. In fact, the small scale of operations of the IEFs is both an incentive to maintain flexibility as is an incentive to be a member of a network of complementary firms through which additional market-related opportunities may emerge. The hybrid form - social network - has been suggested as the best mechanism (in comparison to the hierarchy or the market) given the constraints faced by the IEFs (Powell, 1990). The implications are far reaching and include basic international business decisions. In this paper we delved broadly into two main: the markets where the IEFs operate and the foreign entry modes, but future studies may extend this analysis.

Moreover, we discussed how IEFs are likely to select certain types of markets, and in particular how their focus on foreign market niches is better adjusted to the resource constraints faced. It seems further reasonable our assertion that by deploying their networks of relationships, the IEFs are better able to adapt to the host market niches idiosincrasies. Nonetheless, the IEFs will benefit from selecting the entry modes in each foreign market based on partnerships.

There are multiple possible avenues for future research. We did not consider how specifically the influence of the IEFs' ability to build their networks, but a clear identification how each environmental dimension fosters or constrains the building up of a network is important. Moreover, there are likely industry variations that warrant additional study. For instance, the different requirements that entry into each industry entail (e.g., capital intensity, technology intensity, labor intensity) is likely to influence not only the building of the network but also the composition of the network at each stage of the IEFs life cycle (Li \& Ferreira, 2006). Still focusing on the environment, it has already been acknowledged that culture (national culture) plays a role in the propensity of entrepreneurs to integrate and cooperate within a network of ties. Notwithstanding, several doubts remain unanswered. For instance, how does national culture impact on the formation of a network? We may expect that in more collectivist countries (see Hofstede, 1980) entrepreneurs will tend to rely more often in their informal relationships and it is likely that their networks are composed mainly of informal ties, than in countries such as the US or Germany.

Future research should delve deeper into the understanding of how the IEFs networks evolve over time. We understand that differing resource needs are likely to require an adjustment in the network of ties (e.g. Hite \& Hesterly, 2001), but we do not truly understand how firms add and discard previous ties. An exploration through the lenses of transaction costs theory may be fruitful in this area and helpful in explaining how the IEFs' networks matter for conducting international business. Another future research possibility relies on understanding how the nature of the ties and the position of the IEF in the social network may concede an advantage when entering foreign markets.

To conclude, in this paper we focused on the social networks of international entrepreneurial firms. The social networks are crucial for survival and growth, namely in international markets and more importantly for small firms. The characteristics of the firms and of their operations influence such decisions as market selection and foreign market entry strategies. Social networks' concepts seem to adjust fairly well to the explanation of international entrepreneurial firms. While entrepreneurial actions and strategies seem to be facilitated by prior relationships, the prior ties provide a "safety net" by decreasing general resource dependence constraints and risks, fuelling international expansion by IEFs. 


\section{References}

ALVAREZ, S.A.; and BARNEY, J.B. "How entrepreneurial firms can benefit from alliances with large partners". The academy of Management Executive, vol. 15, nº1, pp.139-148, 2001.

ANDERSSON, S. Internationalization of the firm from an entrepreneurial perspective. International Studies of Management and Organization, vol. 30, $\mathrm{n}^{\circ} .1$, pp. 63-92, 2000.

BARNEY, J. Firm resources and sustained competitive advantage. Journal of Management, vol. 17, nº. 1, pp.99-120, 1991.

BARRINGER, B. R.; BLUEDORN, A. C. The relationship between corporate entrepreneurship and strategic management. Strategic Management Journal, v. 20, n. 5, pp. 421-444, 1999.

BAUM, J. \& SINGH, J. Organizational niches and dynamics of organizational founding. Organization Science, vol. 5, $\mathrm{n}^{\circ}$. 4, pp.483$501,1994$.

BAUM, J.A.C. Organizational ecology. In: CLEGG, S. R., HARDY, C. e NORD, W.R. (eds.) Handbook of organization studies. London: Sage, 1996.

BEAMISH, P. The internationalization process for smaller Ontario firms: A research agenda. In: RUGMAN, M. (Ed) Research in Global Strategic Management-International Business Research for the Twenty-first Century: Canada's New Research Agenda. pp.77-92. JAI Press, Greenwich, 1990.

BEAMISH, P. The role of alliances in international entrepreneurship. In: WRIGHT, R (Ed). Research in Global Strategic Management. vol. 7, pp.43-61. JAI Press, Stanford, CT, 1999.

BELL, J. The internationalization of small computer software firms: A further challenge to 'stage' theories. European Journal of Marketing, vol. 29, nº. 8, pp.60-75, 1995.

BETTIS, R. \& HITT, M. The new competitive landscape. Strategic Management Journal, Vol. 16 (special issue), pp.7-19, 1995.

BLOODGOOD, J. M; SAPIENZA, H. J; ALMEIDA, J. G. The internationalization of new high-potential US ventures: antecedents and outcomes. Entrepreneurship: Theory and Practice, v. 20, n. 4, p. 61-76, 1996.

BONNACCORSI, A. On the relationship between firm size and export intensity. Journal of International Business Studies, v. 23, n. 4, p. 605-635, 1992.

BROMILEY, P.; CUMMINGS, L. Transaction costs in organizations with trust. In: Research and Negociation in Organizations, 193, v. 5, 219-247, Greenwich, CT: JAI Press, 1995.

BURGELMAN, R. A process model of internal corporate venturing in the diversified major firm, Administrative Science Quarterly. vol. 28, pp. 223-244, 1983.

CARRIER, C. Intrapreneurship in large firms and SMEs: a comparative study. International Small Business Journal, vol. 12, $\mathrm{n}^{\circ} .3$, pp. 54-61, 1994.

CARROLL, G. A stochastic model of organizational mortality: Review and reanalysis. Social Science Quarterly. vol. 34, pp. 411-430, 1983.

CAVES, R. \& PORTER, M. From entry barriers to mobility barriers: Conjectural decisions and conceived deterrence to new competition, Quarterly Journal of Economics, pp.241-260, 1977.

CAVUSGIL, S. On the internationalization process of firms. European Research, vol. 8, pp.273-281, 1980.

CHETTY. S. \& HAMILTON, R. The process of exporting in owner-controlled firms. International Small Business Journal, vol. 14, $\mathrm{n}^{\circ} .2$, pp.12-25, 1996.

COVIELLO, N. \& MCAULEY, A. Internationalization and the smaller firm: A review of contemporary empirical researches. Management International Review, vol. 39, nº. 3, pp.223-256, 1999.

COVIELLO, N. \& MUNRO, H. Growing the entrepreneurial firms: Networking for international market development. Europe Journal of Marketing, vol. 29, $\mathrm{n}^{\circ} .7, \mathrm{pp} .49-61,1995$.

COVIELLO, N. \& MUNRO, H. Network Relationships and the internationalization process of small software firms. International Business Review, vol. 6, nº. 2, pp.1-26, 1997.

DALGIC, T., LI, L. \& LI, D. Internationalization Process of Small and Medium-sized Enterprises: Toward a Hybrid Model of Experiential Learning and Planning, Management International Review, vol.44, nº.1, pp. 93-116, 2004.

DALLI, D. The exporting process: The evolution of small and medium-sized firms towards internationalization. Advance in International Marketing, vol. 6, pp.85-110, 1994. 
DE CLERCQ, D., SAPIENZA, H.J., CRIJNS, H. The internationalization of small and medium-sized firms: the role of organizational learning effort and entrepreneurial orientation. Small Business Economics. vol. 24, nº. 4, pp. 409 -419, 2005.

DIMITRATOS, P., JOHNSON, J., SLOW, J. \& YOUNG, S. Micromultinationals: New.types of firms for the global competitive landscape. European Management Journal, vol. 21, nº. 2, pp.164-174, 2003.

DUNNING, J. Explaining the international direct investment position of countries: Towards a dynamic and development approach, Weltwirtschaftliches Archiv, vol. 117, pp.30-64, 1981.

DYER, J. \& SINGH, H. The relational view: Cooperative strategy and sources of interorganizational competitive advantage. Academy of Management Review. vol. 23, $\mathrm{n}^{\circ}$. 4, pp.660-679, 1998.

FERNHABER, S., MCDOUGALL, P. \& OVIATT, B. Exploring the Role of Industry Structure in New Venture Internationalization. Entrepreneurship Theory and Practice, vol. 31, pp. 517-542, 2007.

FONTES, M. \& COOMBS, R. The coincidence of technology and market objectives in internationalization of new technology-based firms, International Small Business Journal, vol. 15, nº. 4, pp.14-35, 1997.

FREEMAN, S., EDWARDS, R. \& SCHRODER, B. How smaller born-global firms use networks and alliances to overcome constraints to rapid internationalization. Journal of International Marketing, vol. 14, nº. 3, pp.33-63, 2006.

GANKEMA, H., SNUIT, H. \& VAN DIJKEN, K. The internationalization process of small and medium-sized enterprises: an evaluation of the stage theory. In: Donckels. R. and Miettinen, A. (Eds.), Entrepreneurship and SME research: On its way to the next millennium. Aldershot: Ashgate Publishing Ltd., pp. 185-197, 1997.

GRANOVETTER, M.. Economic action and social structure: the problem of embeddedness. American Journal of Sociology, vol. 91, pp.481-510, 1985.

GUISINGER, S. From OLI to OLMA: Incorporating higher levels of environmental ad structural complexity into the Eclectic paradigm. International Journal of the Economics of Business, vol. 8, $\mathrm{n}^{\circ} .2$, pp.257-272, 2001.

GULATI, R. Does similarity breed trust? The implications of repeated ties for contractual choice in alliance. Academy of Management Journal, vol. 38, $\mathrm{n}^{\circ} .1, \mathrm{pp} .85-112,1993$.

GULATI, R. Alliance Formation. Administrative Quarterly Science. vol. 40, pp.619-652, 1995.

GULATI, R., \& SINGH, H. The architecture of cooperation: Managing coordination costs and appropriation concerns in strategic alliances. Administrative Science Quarterly, vol. 43, nº. 4, pp.781-814, 1998.

HANNAN, M., \& FREEMAN, J. Organizational Ecology. Cambridge, MA: Harvard University Press, 1989.

HANSEN, M. T. The search-transfer problem: the role of weak ties in sharing knowledge across organization subunits. Administrative Science Quarterly, v. 44, n. 1, pp. 82-111, 1999.

HITE, J., \& HESTERLY, W. The evolution of firm networks: From emergence to early growth of the firm. Strategic Management Journal, vol. 22, pp.275-286, 2001.

HITT, M., REED, T. Entrepreneurship in the New Competitive Landscape. In: MEYER, G., HEPPARD (Eds.) Entrepreneurship as Strategy: Competing on the Entrepreneurial Edge, Thousand Oaks, CA: Sage Publications, pp. 23-48, 2000.

HOFSTEDE, G. Culture's consequences: International differences in work-related values. Beverly Hills and London, Sage, 1980.

HOLMLUND, M., \& KOCK, S. Relationships and the internationalization of Finnish small and medium-sized companies. International Small Business Journal, vol. 16, nº 4, pp.46-63, 1998.

HULSINK, W., ELFRING, T. \& STAM, W. The locus of innovation in small and medium-sized firms: The importance of social capital and networking in innovative entrepreneurship, Research Paper ERS-2008-041-ORG, Erasmus Research Institute of Management (ERIM), 2008.

HUMAN, S., \& PROVAN, K. Legitimacy building in the evolution of small firm mutilateral networks: A comparative study of success and demise. Administrative Science Quarterly, vol. 45, nº. 2, pp.327-369, 2000.

HYMER, S. International operations of national firms: A study of direct foreign investment. Cambridge, MA: MIT Press, 1976.

IBARRA, H.. Network centrality, power, and innovation involvement: Determinants of technical and administrative roles. Academy of Management Journal. vol. 36, nº. 3, pp.471-501, 1993.

JANTUNEN, A., PUUMALAINEN, K.,SAARENKETO, S. \& KYLÄHEIKO, Kalevi Entrepreneurial orientation, dynamic capabilities and international performance, Journal of International Entrepreneurship, Vol. 3, No.3, pp. 223-243, 2005.

JARILLO, J. On strategic network. Strategic Management Journal. Vol. 9, pp.31-41, 1998. 
JARILLO, J. C. Entrepreneurship and growth: The strategic use of external resources. Journal of Business Venturing, Vol. 4, pp. 133147,1989 .

JOHANSON, J. \& VAHLNE, J-E. The mechanisms of internationalization. International Marketing Review, Vol. 7, No. 4, 11-24, 1990.

JOHANSON, J., \& VAHLNE, J. The internationalization process of the firm: A model of knowledge development and increasing foreign market commitment. Journal of International Business Studies. Spring/Summer, pp.23-32, 1977.

JOLLY, V.K., ALAHUNTA, M; Jeannet, J.-P. Challenging the incumbents: How high technology start-ups compete globally. Journal of Strategic Change, Vol. 1, pp. 71-82, 1992.

JONES, C., HESTERLY, W. \& BORGATTI, S. A general theory of network governance: Exchange conditions and social mechanisms. Academy of Management Review. Vol. 22, No. 4, pp. 911-46, 1997.

KARLSEN et al. Knowledge internationalization of the firm, and inward-outward connections. Industrial Marketing Management, Vol. 32, pp.385-396, 2003.

KIMBERLY, J. Managerial innovation, In: Nystrom, P. C. and Starbuck, W. H. (Eds.), Handbook of Organizational Design, Vol. 1, pp.84-104. New York: Oxford University Press, 1981.

KNIGHT, G. \& CAVUSGIL, S. The born global firm: A challenge to traditional internationalization theory. In: T. K. Madsen (Ed.). Advances in international marketing, Vol. 8, pp.11-26. Greenwich, CT: JAI, 1996.

KNIGHT, G. \& CAVUSGIL, S. Innovation, organizational capabilities, and the born-global firm, Journal of International Business Studies, Vol. 35, No. 2, pp.124-141, 2004.

LAMIERI, M. \& IETRI, D. Innovation creation and diffusion in a social network: an agent based approach, MPRA Paper 445, University Library of Munich, Germany, 2006.

LARSON, A. Partner network: Leveraging external ties to improve entrepreneurial performance. Journal of Business Venturing., Vol. 6, pp.173-188, 1992.

LARSON, A., \& STARR, J. A network model of organization formation. Entrepreneurship Theory and Practice. Vol. 17, No. 2, pp.5-15, 1993.

LI, D. \& FERREIRA, M.. The evolutionary model of entrepreneurial firms' dependence on networks: Going beyond the start-up stage. Notas Económicas, Vol. 8, pp.48-63, 2006.

LU, J. \& BEAMISH, P. The Internationalization and Performance of SMEs. Strategic Management Journal, Vol. 22, pp.565-586, 2001.

LUMPKIN, G. \& DESS, G. Clarifying the entrepreneurial orientation construct and linking it to performance. Academy of Management Review. Vol. 21, No. 1, pp.135-172, 1996.

OMAR, M.,NWANKWO, S. \& RICHARDS, D. Determinants of internacional entepreneurship of UK companies. World Review of Entrepreneurship, Managemente and Sustainable Development, Vol. 4, No. 1, pp.1-18, 2008.

MADSEN, T. \& SERVAIS, P. The internationalization of born globals: An envolutionary process. International Business Review. Vol. 6, pp.561-583, 1997.

MAJKGARD, A. \& SHARMA, D. Client-following and market-seeking strategies in the internationalization of service firms. Journal of Business-to-Business Marketing, Vol. 4 No.3, pp.1-41, 1998.

MATHEWS, J. \& ZANDER, I. The international entrepreneurial dynamics of accelerated internationalisation, Journal of International Business Studies, Vol. 38, No. 3, pp.387-403, 2007.

MCAULEY, A. Entrepreneurial Instant Exporters in the Scottish Arts and Crafts Sector, Journal of International Marketing, Vol. 7, No. 4, pp. 67-82, 1999.

MCDOUGALL, P. \& OVIATT, B. Global start-ups: New ventures without geographic limits. The Entrepreneurship Forum. Winter, $1-5,1991$.

MCDOUGALL, P. International versus domestic entrepreneurship: New venture strategic behavior and industry structure. Journal of Business Venturing. Vol. 4, pp.387-399, 1989.

MCDOUGALL, P., SHANE, S. \& OVIATT, B. Explaining the formation of international new ventures: the limits of theories from international business research. Journal of Business Venturing. Vol. 9, pp.469-487, 1994.

MILLER, D. \& FRIESEN, P. Archetypes of strategy formulation. Management Science. Vol. 24, pp.921-933, 1982.

MILLER, D.. The correlated of entrepreneurship in three types of firms. Management Science. Vol. 29, pp.770-791, 1983. 
MOEN, O. The born globals: a new generation of small European exporters. International Marketing Review, Vol. 19, No.2, pp.156175,2002

OVIATT, B. \& MCDOUGALL, P. Toward a theory of international new ventures. Journal of International Business Studies. Vol. 25, No. 1, pp.45-64, 1994.

OVIATT, B. \& MCDOUGALL, P. Global start-ups: Entrepreneurs on a worldwide stage. Academy of Management Executive, Vol. 9 , No.2, pp.30-43, 1995.

PFEFFER, J. \& SALANCIK, G. The external control of organizations: A resource dependence perspective. New York: Harper and Row, 1978.

POWELL, W. Neither markets nor hierarchies: Network forms of organizations. Research in Organization Behavior. Vol. 12, pp.295336, 1990.

PREECE, S.B., MILES, G. \& BAETZ, M. C. Explaining the International Intensity and Global Diversity of Early-Stage TechnologyBased Firms. Journal of Business Venturing, vol.14, pp.259-281, 1999.

RENNIE, M. Born global. The McKinsey Quarterly, No. 4, pp.45-52, 1993.

SCHUMPETER, J. Capitalism, socialism and democracy. Cambridge, MA: Harvard University Press, 1950.

SCHWART, R., MCCORKLE, D. \& ANDERSON, D. Niche marketing. Texas Agricultural Extension Service, Texas A\&M University System, 2000.

SCOTT, W. R. Organizations: Rational, natural and open systems. Fourth edition, Prentice Hall, 1998.

SHRADER, R., OVIATT, B. \& MCDOUGALL, P. How new ventures exploit trade-offs among international risk factors: Lessons for the accelerated internationalization of the 21st century. Academy of Management Journal, Vol. 43, No. 6, pp.1227-1248, 2000.

STINCHCOMBE, A.. Social structure and organizations. In: March, James (Ed.) Handbook of Organizations, pp.142-193, Chicago, Rand McNally, 1965.

STUART, T., \& PODOLNY, J. Local search and the evolution of technological capabilities. Strategic Management Journal, Vol. 17, pp.21-39, 1996.

STUART, T., HOANG, H. \& HYBELS, R. Internationalization endorsements and the performance of entrepreneurial ventures. Administrative Quarterly Science. Vol. 44, pp.315-349, 1999.

WELCH, L. S. The use of alliances by small firms in achieving internationalization. Scandinavian International Business View, Vol. 1, No. 2, pp.21-37, 1992.

WILLIAMSON, O. The economic institutions of capitalism: Firms, markets, relational contracting. New York, Free Press, 1985.

ZAHRA, S., IRELAND, R. \& HITT, M. International expansion by new venture firms: International diversity, mode of market entry, technological learning, and performance. Academy of Management Journal. Vol. 43, No. 5, pp.925-950, 2000.

ZAHRA, S. A.; GEORGE, G. Absortive capacity: a review, reconceptualization, and extension. Academy of Management Review, v. 27, n. 2, pp. 184-203, 2002. 